\title{
A Study of School Size Among Alabama’s Public High Schools
}

\author{
RONALD A. LINDAHL \\ Alabama State University \\ PATRICK M. CAIN, SR. \\ Capitol Heights Middle School, Montgomery, AL
}

\begin{abstract}
The purpose of this study was to examine the relationship between the size of Alabama's public high schools, selected school quality and financial indicators, and their students' performance on standardized exams. When the socioeconomic level of the student bodies is held constant, the size of high schools in Alabama has relatively little relationship with 11th grade student (both regular and special education) performance on the reading and math portions of the Alabama High School Graduation Exam (AHSGE). High schools' average daily attendance rates and pupil-to-computer (and computer with Internet connections) ratios do not vary in accordance with school size. Higher percentages of highly qualified teachers are found in Alabama's largest high schools. There was very little difference in the percentage of teachers with a master's degree or above across school size categories. Very little difference exists across size categories in regard to mean expenditures per pupil (range $=\$ 7,322$ to $\$ 7,829$ ). However, districts of the large high schools exert over twice the effort of those with small high schools (3.2 mills to 1.5 mills) and approximately 50 percent greater local effort than the districts of the medium-size high schools.
\end{abstract}

Lindahl, R. A. \& Cain, P. M., Sr. (2012). A Study of School Size among Alabama's Public High Schools. International Journal of Education Policy and Leadership 7(1). Retrieved from www.ijepl.org.

Determining the ideal size for high schools has been the focus of many research studies and of much debate over the past half-century. During the 1960s, there was a movement away from ever larger high schools to smaller, alternative schools; e.g., Sizer's Coalition of Essential Schools, which focused on student-centered education (Semel \& Sadovnik, 2008). Over the past decade, this movement has experienced a renewal, with the development of schoolswithin-schools (large high schools subdivided into several smaller schools operating simultaneously in the same facility), thematic curriculum schools (Jaffe-Walter, 2008; Ready \& Lee, 2008), and the Bill and Melinda Gates Foundation's efforts to establish small high schools in urban areas (Semel \& Sadovnik; Shear et al., 2008). Urban schools, particularly, have been strongly criticized for attempting to serve large student bodies, which depersonalizes the stu- dent learning experience and causes some students to feel marginalized and ignored (McQuillan, 2008).

Partially, this debate is a consequence of population dynamics. Since 1940, the number of U.S. public schools has fallen by almost 70 percent, while the average school size has risen by 400 percent; during this period, urban growth has escalated greatly. As of 2004, approximately half of all U.S. public high schools served more than 1,500 students, with many urban high schools serving over 5,000 students (Werblow \& Duesbery, 2009, p. 14). However, in the decade following 1993, the number of high schools nearly doubled as small schools opened and large schools were reorganized into smaller schools (Iatarola, Schwartz, Stiefel, \& Chillman, 2008). The National Center for Education Statistics (2009) reported that for the school year 2007-2008, the average size of 
regular secondary schools was 816 students. This ranged from an average of only 166 in South Dakota to an average of 1,667 in Florida. Nationwide, 44 percent of regular secondary schools served 1,500 students or more (National Center for Education Statistics, Table 94).

However, much of the debate and stimulus for research arises from the perceived benefits of larger and smaller schools. Leithwood and Jantzi (2009, pp. 464-465) summarized these contrasting perceptions. Larger schools were perceived to offer:

- An increased variety of classes;

- An increased specialization of teachers;

- A greater likelihood to draw a diverse population, thereby increasing students' exposure to diversity;

- More stimulating classes;

- Less pigeonholing or stereotyping of students; and

- Greater opportunities for students to develop social relationships.

On the other hand, smaller schools were perceived to offer:

- Faculty and staff who know students well;

- Faculty who take greater responsibility for student learning;

- Increased connections between students and the community;

- Better teaching strategies; and

- Less need for monitoring and supervision. Although considerable research has been done on optimal size for high schools, the results are mixed and are certainly not definitive (Leithwood \& Jantzi).

\section{Purpose of the Study}

The purpose of this study was to examine the relationship between the size of Alabama's public high schools, selected school quality and financial indicators, and their students' performance on standardized exams.

\section{Research Questions}

The research questions guiding this study were:
1. What are the demographic characteristics (number of pupils, school grade level configurations, Title I eligibility, percentage of students qualifying for free or reduced price lunch, and percentages of white or minority students served) of Alabama's public high schools, by school size?

2. To what extent do Alabama's public high schools vary in average daily attendance, number of pupils per computer in the classroom, number of pupils per computer with Internet access, percentage of teachers with a minimum of a master's degree, and percentage of highly qualified teachers, by school size?

3. To what extent do Alabama's public high schools vary in expenditures per pupil and local tax effort, by school size?

4. To what extent do Alabama's public high schools vary in student performance on the math and reading portions of the Alabama High School Graduation Exam (AHSGE) by school size?

5. To what extent do relationships among these variables vary by school size?

6. To what extent do the school quality indicators (average daily attendance, number of pupils per computer in the classroom, number of pupils per computer with Internet access, percentage of teachers with a minimum of a master's degree, and percentage of highly qualified teachers) and school size predict student performance on the math and reading portions of the AHSGE?

7. To what extent do the relationships between student performance on the math and reading portions of the AHSGE and school size vary by the socioeconomic backgrounds of the students?

\section{Review of Related Literature}

Considerable research has been conducted on the relationship between the size of high schools and student performance variables, expenditures per student, dropout rates, school climate and culture, and variables related to the school curriculum. That research is summarized in the sections that follow. Although 
broader in scope than the specific variables examined in this study, the review of the knowledge base that follows provides important background information on a range of issues related to high school size.

\section{Student Performance}

The most common variable studied in relation to high school size has been student performance on standardized examinations. Admittedly, considerable controversy exists regarding the use of this variable as a sole indicator of student learning (Ravitch, 2010). Standardized tests measure a restricted range of knowledge and do so in a limited range of performance formats, primarily multiple-choice responses. However, because such exams allow for widespread comparability of scores and reduced inter-rater variability as compared to more authentic forms of evaluation, they have become the most-used measure for research studies of this nature.

In examining standardized test results in relation to school size, considerable variation exists in the results. In part, this variation may derive from the inconsistent categorization of schools by size. For example, Ornstein (1990) referred to an uncited ten-year study of Illinois high schools, in which the small school category ranged from 495 to 1,280 students, whereas in Lee's 2000 study, the small school category included only schools under $300 \mathrm{stu}-$ dents and Johnson's 2006 study classified such schools as being below 200 students. Overall school size can be a deceptive variable, as schools contain varying numbers of grade levels, from 13 grades to only three or four. Consequently for this study, the size of the 11th grade was chosen to represent school size.

In part, this variation may be attributable to the variety of standardized examinations utilized, each with its own degrees of validity and reliability. For example, Lee and Smith (1997) examined data from the National Educational Longitudinal Study: 1988 (NELS:88), whereas Schneider, Wyse, and Kessler (2007) and Werblow and Duesbery (2009) used data for the National Educational Longitudinal Study: 2002, and Gardner, Ritblatt, and Beatty (2000) examined scores on the Scholastic Aptitude Test (SAT). Leithwood and Jantzi (conducted a meta-analysis on 18 studies; unfortunately, they did not specify which examinations were used in those studies. Likewise, they did not specify their methodology in conducting the meta-analysis and reported effect sizes for only three studies.

The methodological limitations notwithstanding, the analysis of standardized exam results by school size are clearly inconclusive (Iatarola et al., 2008). In their meta-analysis of 18 studies on the relationship between high school size and student performance, Leithwood and Jantzi (2009) concluded that five studies found a positive relationship, whereas eight studies found a negative relationship. Six studies identified the relationship as an "inverted U," where achievement related positively to school size until an optimal size was reached, at which point the relationship became negative. Effect sizes in all studies ranged from very small (-.00075) to moderate (-.30), at best.

Lee and Smith (1997) and Lee (2000) found that students in moderate-size schools (600 to 900 students) scored higher than students in smaller or larger schools, whereas Werblow and Duesbery (2000) found the opposite, with math gain highest in the very large or very small schools. Johnson (2006) found that students in small schools (below 200 students) had the highest math and reading scores, the opposite of the findings of Gardner, Ritblatt, and Beatty (2000) and Schneider, Wyse, and Kessler (2002), who found that the students in the larger schools had the highest performance. Wyse, Kessler, and Schneider (2008) concluded that switching students to small schools from large schools would not raise math achievement and that there is no relationship between these two variables.

Not all studies controlled for the socioeconomic backgrounds of the students. However, Ornstein (1990) referred to an uncited ten-year study of Illinois high schools, in which the lowest student achievement on standardized 
tests was in the smallest schools $(<495$ to 1,280 students), even when socioeconomic status and geographical location were controlled. However, schools with over 1,000 students were found to be less effective on this variable than somewhat smaller schools, suggesting a nonlinear relationship. Leithwood and Jantzi's (2009) meta-analysis reached similar conclusions based on five of the 18 studies they examined, yet Lee (2000) found the opposite, especially for reading scores.

Among the studies identifying a non-linear relationship was that of Lee and Smith (1997), which was based on hierarchical linear modeling and used the National Educational Longitudinal Study: 1988 (NELS:88) database (National Center for Educational Statistics, 1995). Students in high schools with between 600 and 900 students scored best in both reading and math. In smaller schools, students performed less well; in larger schools, especially those with over 2,100 students, students performed considerably less well. Lee's (2000) study of 789 public and private high schools also used the math and reading scores from the NELS:88 database. Lee concluded that "students in moderately sized schools, particularly in the 600 to 900 student range, learn most. Although learning is low in the smallest schools (i.e., under 300 students), for both subjects, gains are lowest in the largest schools (i.e., over 2,100 students)" (p. 131).

Werblow and Duesbery's 2009 study utilized national data on 752 high schools from the Educational Longitudinal Study of 2002 (U.S. Department of Education, 2005). They also found a curvilinear relationship between student performance and high school size, with math gain highest in very large or very small schools. However, over the last two years of high school, only 5 percent of the differences in math growth was attributed to school size (p. 21). These findings complemented Schneider, Wyse, and Kessler's 2007 study using the same database, which concluded that the greatest math achievement occurred in schools with more than 2,000 students.
Different results were presented in Johnson's (2006) study on Iowa's small, rural high schools, which found that districts with high school enrollments of $\leq 200$ produce higher scores in math and reading. However, beyond this, no relationship was found between student performance and school size in this study.

Yet different results were found by Gardner, Ritblatt, and Beatty in their 2000 study of large and small high schools in California. They found that larger high schools have higher academic achievement on the Scholastic Aptitude Test (total, math, and verbal scores) than do smaller high schools. Additionally, larger high schools had a higher proportion of students taking the examination.

Another aspect of student performance on standardized examinations is the extent to which this performance is equitably distributed across students of different socioeconomic backgrounds. Lee's (2000) national study of 789 public and private high schools, using NELS:88 data, found learning to be most equitably distributed in larger schools (p. 133), with the effects of size more equitably spread across socioeconomic groups in reading than in math. Lee concluded that school size makes a greater difference in schools enrolling students of low socioeconomic status than in those serving students of higher socioeconomic status. Leithwood and Jantzi's (2009) metaanalysis of five empirical studies reached an opposite conclusion: students of low socioeconomic status are better off in smaller schools, whereas those of higher socioeconomic status are equally well off in both large and small schools.

\section{Expenditures Per Student}

Various studies have examined the relationship between expenditures per pupil and high school size. Stiefel, Berne, Iatarola, and Fruchter (2000) studied New York City high schools and concluded that their budgets-pergraduate were similar, regardless of size. Expenditures-per-graduate is a slightly different measure than expenditures-per-student, as it discounts the dropout rate. Leithwood and 
Jantzi (2009) found that it was difficult to conduct a meta-analysis of studies relating school size to cost per student because of the varied methods used to define variables. In the analysis of five studies on cost efficiency, they found two to favor larger schools, two to favor smaller schools, and one to favor mid-sized schools. Iatarola et al. (2008) found that small schools have higher per-pupil expenditures, partially because of lower student/teacher ratios.

These studies examined only operations and maintenance ( $\mathrm{O} \& \mathrm{M}$ ) costs, the yearly budget of the school for salaries, benefits, supplies, transportation, and similar expenses. These expenses do not present the full picture of expenditures per student, because they omit the initial capital outlay of building and equipping the school, debt repayment, and large-scale maintenance or renovation. The use of the $\mathrm{O} \& \mathrm{M}$ costs is at least partially vindicated by the findings of Howley (2008), who examined the construction costs of larger versus smaller high schools in the United States. He concluded that the smaller half of the high schools he examined (with planned enrollment from 138 to 600 students) were no more expensive per student to build than the schools in the larger half, which had planned enrollments of 601 to 999 students. Furthermore, he found that the smaller schools were less costly per square foot, although they allocated 26 percent more space per student when compared to the larger schools. Consequently, construction costs per student did not vary greatly by school size.

\section{Local Tax Effort}

In school finance, horizontal equity refers to the concept that similarly situated students would be funded similarly. For example, students in poor school districts would be funded as well as their peers in wealthier districts. Vertical equity refers to the concept that students should be funded differentially based on their individual educational needs. For example, severely handicapped students may require greater funding than the average student. In Alabama, the state school finance formula at- tempts to provide horizontal equity across school districts by requiring a minimum level of effort. The state then provides funding to equalize the per-pupil resources of rich and poor districts up to the minimum adequacy level. Further adjustments are made by the state to address vertical equity (e.g., additional funding for children with special needs or transportation adjustments). However, districts also have the option of levying additional local taxes (measured in mills, or one-thousanths of a dollar of assessed property valuation) to supplement the minimum foundation program. This is generally referred to as local effort. To some extent, it reflects the importance people in the district place on their public schools.

\section{Free or Reduced Price Lunch}

Since the classic 1972 study by Jencks et al., students' socioeconomic backgrounds have consistently been recognized as a major determinant of their performance on standardized tests, so much so that it is a variable almost universally incorporated into equations to determine students' projected test scores. Although exceptional schools have been able to overcome the negative influences of poverty, it remains a predominant factor in student learning. For purposes of this study, the percentage of students in the school who were eligible for free or reduced price lunches under the federal guidelines of the Department of Agriculture was used as a surrogate variable for student socioeconomic background. This surrogate variable was a methodological limitation, as it is widely recognized that because of social pressures, not all high school students who would qualify for such assistance would indicate their eligibility.

\section{Qualifications of Teachers}

Relatively little research exists on teacher qualifications and high school size. The primary study in the field is Monk and Haller's 1993 study on 682 public high schools that participated in the High School and Beyond Survey (National Opinion Research Center, 1987). 
They found a relationship between school size and the availability of teachers and the adequacy of their certification and preparation for the courses they teach. However, they also found that school size was autocorrelated with the urban, suburban, or rural location of the high schools, which may have been the true determining factor in teacher availability and qualifications. In this study, the percentage of "highly qualified" teachers in each school was used as a surrogate measure of the extent to which teachers were teaching in the fields for which they were certified. Alabama's federally accepted definition of "highly qualified" was followed.

Although Kahne et al. (2008) did not examine teacher qualifications per se, their case study research on large Chicago high schools that had been converted to smaller schools did examine teacher behaviors, a related issue. They concluded that the teachers in the smaller schools were more collegial, more committed, and provided more academic and personal support for students than did teachers in larger schools. However, they did not discern any differences in the quality of instruction between the two size groups. No description was provided as to how the quality of teaching was assessed, which indicates the potential subjectivity of this conclusion.

\section{Key Variables Not Examined in This Study}

Because Alabama's Department of Education releases much of the data on its education system aggregated at the district level rather than at the school level, this study was limited as to the variables that could be examined. Noticeably, and regrettably, absent from this study are the variables related to the school's dropout rate, students' participation in extracurricular activities, the breadth and depth of the school curriculum, the school's climate and culture, and student discipline rates in the school. Nevertheless, a brief review of the research base on these variables serves to put this study into its wider context and to highlight possibilities for further study in the future.

\section{Dropout rates}

One measure of student achievement is a school's dropout rate. Unfortunately, Alabama presents these rates aggregated at the district level, not the individual school level. Consequently, this variable could not be examined in this study. Furthermore, until most recently, with new federal guidelines, the calculation and reporting of reliable dropout data have long been questioned. Nevertheless, previous findings are discussed briefly here as a contextual variable and as a performance variable for future studies.

Much like standardized test scores, the relationship of high school size to dropout rates is clearly inconclusive. Gardner et al. (2000), Lee and Burkham (2003), Pittman and Haughwout (1987), and Werblow and Duesbery (2009) all found weak, positive relationships between dropout rates and high school size. However, Leithwood and Jantzi's (2009) meta-analysis of 13 empirical studies on high school size and dropout rates found that one study found a positive relationship between dropout rates and school size, and five found a negative relationship. Three other studies found a nonlinear relationship between school size and dropout rates, with mid-sized schools performing best. Finally, four studies found no significant relationship between these two variables. Kahne, Sporte, de la Torre, and Easton (2008) studied large Chicago high schools that had been converted to smaller schools. They found a decreased dropout rate with this conversion, but only for the initial cohort. There was no difference in the dropout rate for the second cohort.

Numerous studies have been conducted to investigate the relationship between dropout rates and high school size. In their 1987 national study based on High School and Beyond Survey (National Opinion Research Center, 1987) data, Pittman and Haughwout examined 744 public high schools and found a weak, significant $(r=.31, p \leq .05)$ relationship between 
high school size and dropout rates. Similar results were found by Gardner et al. (2000) in their study of California high schools. Lee and Burkham's (2003) study examined 190 urban and suburban high schools, using data from the High School Effectiveness Supplement to the National Educational Longitudinal Study of 1988 (Scott, Ingels, Shera, Taylor, \& Jergovic, 1996). They found that in schools that offer mainly academic courses and few nonacademic courses, students were less likely to drop out. They also found that students in schools with a population of less than 1,500 students were likely to stay in school. Werblow and Duesbery (2009) used data on 752 high schools from the Educational Longitudinal Study of 2002 (U.S. Department of Education, 2005). They found a similar positive relationship between high school size and dropout rates: "A gentle increase in school size is associated with a $12 \%$ increase in the average student dropout rate. Also, rural schools had a 30\% higher student dropout rate than suburban schools, and for every $10 \%$ increase in students on free and reduced lunch, schools experience a small but significant increase in student dropout rate" (p. 19).

Monk and Haller's (1993) examination of the High School and Beyond Survey (national Opinion Research Center, 1987) revealed that school size was autocorrelated with the urban, suburban, or rural location of high schools. This, in turn, may confound conclusions regarding the relationship of high school size to dropout rates. In 2008-2009, the primary school districts of the nation's largest cities had dropout rates of 47.2 percent, with more than a quarter of a million students failing to graduate within the traditional four years. This represents approximately one-fourth of the dropouts nationwide, but only about 12 percent of the nation's students who entered high school (Editorial Projects in Education, 2009).

\section{Participation in extracurricular activities}

One measure of school quality not directly related to academic performance is student participation in extracurricular activities. The un- derlying premise behind this variable is that such activities help to develop the whole child. Kleinert (1969) studied 63 high schools in southern Michigan and found a striking decrease in student involvement in the activity programs of larger high schools as compared with the participation rate in smaller schools (p. 36). This involvement differential was reflected in total student participation, the proportion of students who participate, the number of student leadership roles per student, and the number of activity offerings per student. Schoggen and Schoggen's 2001 study of 27 public high schools in central New York State found a moderate, negative correlation $(r=$ $-.69, p \leq .05)$ between high school size and the mean number of participations in extracurricular activities. Leithwood and Jantzi's 2009 metaanalysis of previous empirical studies identified four studies that found a negative, linear relationship between high school size and overall student engagement. They also described four studies that found a significant positive, linear relationship between school size and participation in extracurricular activities.

However, as with student performance and dropout rates, the relationship of participation in extracurricular activities to high school size is not fully established. The majority of the studies examined found that students in smaller high schools tended to be more active in extracurricular activities than their peers in larger schools (Iatarola et al., 2008; Kleinert, 1969; Schoggen \& Schoggen, 2001). Leithwood and Jantzi's (2009) meta-analysis supported this for four of the studies examined, yet they identified another four studies in which greater student participation was found in the larger schools. Schoggen and Schoggen reported an interesting finding on participation in extracurricular activities. In the 27 central New York State high schools studied, there was a moderate, positive correlation $(\mathrm{r}=.77, \mathrm{p} \leq .05)$ between school size and students' failure to participate in any extracurricular activities. This total nonparticipation warrants considerable further study, as these students are clearly 
highly at risk as potential dropouts and for other psychosocial reasons.

\section{Breadth and depth of the school curricu- lum}

Another indicator of school quality has been assumed to be the breadth and depth of its curriculum. There seemed to be a consensus among the research studies that larger high schools offer a more diverse curriculum than their smaller counterparts (Iatarola et al., 2008). The results of Lee, Smerdan, Afeld-Liro, and Brown (2000), Leithwood and Jantzi (2009), Monk and Haller (1993), and Pittman and Haughwout (1987) all supported this conclusion. Moreover, Lee et al. conducted interviews in six public high schools and found that in the smaller schools, curricular offerings were generally targeted to students of average ability rather than to varying ability levels. In the three large high schools they studied, a broad, but not very deep, curriculum predominated, whereas in the smaller schools, the focus was on basic middle-level courses rather than on specialized courses such as home economics, industrial arts, or calculus. Students in smaller high schools appeared to be less "anonymous" than in the larger schools.

\section{School climate and culture}

A variety of school climate variables have been examined in relationship to high school size, with the underlying assumption being that these have an indirect influence on student learning. These variables include such aspects as participation in extracurricular activities, diversity of the curriculum, availability and qualifications of teachers, and discipline. Pittman and Haughwout (1987) examined 744 public high schools that participated in the High School and Beyond Survey (National Opinion Research Center, 1987) and found that school size had a weak, positive relationship ( $r=.31, p$ $\leq .05)$ with the overall climate of the school. McQuillan (2008) noted that large high schools have a lack of institutional focus and suffer because of their size. Their students are not active participants in democratic educational practices and sense a cultural disjuncture from the school. Their teachers suffer from a lack of trust and collectivity, work in isolation, and hold lower expectations for students (see also Jaffe-Walter, 2008, and Shear et al., 2008). Kafka (2008) found that small schools had a culture of progressivism and social justice, in which students were nurtured and formed stronger personal relationships and bonds than in larger schools. Maroulis and Gomez (2008) conducted social network analyses and concluded that both the density of students' interactions in small schools and peer achievement levels combine to affect student performance.

\section{Student discipline}

Haller (1992) examined data on 558 public high schools that participated in the High School and Beyond Survey (National Opinion Research Center, 1987) and found school size to be moderately and negatively related to student discipline, except for self-reported disorderliness. Haller concluded that "school size has a relatively substantial independent effect on truancy and disorderliness" (p. 152).

\section{Summary}

Considerable research has been conducted to determine the relationship between high school size and student achievement, dropout rates, school culture and climate, and cost efficiency. Although Leithwood and Jantzi's (2009) metaanalysis of 57 of these studies from 1990 to 2007 concluded that "smaller schools are generally better for most purposes" (p. 484), the results of these studies are far from conclusive in any area. Against this knowledge base backdrop, the current study sought to examine these relationships in relation to Alabama's public high schools.

\section{Methodology}

The population examined in this study was the group of 85 Alabama public schools serving 11 th grade students that reported full student 
performance data (including data for both regular and special education students) for the 2003-2004 to 2006-2007 school years, excluding those schools serving unique populations (e.g., alternative schools and detention centers). All data were taken from Alabama State Department of Education (ALSDE) websites and all variables were aggregated at the school level, except for the financial variables, which were only available at the district level. All data were the most recent available; this represented a methodological limitation, as the demographic characteristics of the schools, school quality indicators, and financial indicators were all for school year 2006-2007, whereas the test score data came from school years 2003-2004, 2004-2005, 2005-2006, and 2006-2007. Multiple years of test score data were examined because scores tend to vary somewhat from one year to another, due to test variability and to the specific cohorts of students taking the test, whereas the other variables tend to be more stable over time. The 11 th grade was chosen as the focus for this study because it is at this grade level that all Alabama high school students are expected to be proficient on the statewide graduation examination. Data on 11th grade students' performance on the AHSGE were taken from the Alabama High School Graduation Examination Overview (Alabama State Department of Education, 2007). All other school data were taken from the Annual Data Report: 2005-2006 (Alabama State Department of Education, 2008).

\section{Findings}

This section presents the findings of this study structured to address each research question.

\section{Research Question One}

Research Question One asked: What are the demographic characteristics (number of pupils, school grade level configurations, Title I eligibility, percentage of students qualifying for free or reduced price lunch, and percentages of white or minority students served) of Alabama's public high schools, by school size?
Table 1 (page 16) shows the average size of the 11th grade in all four school categories (small, medium small, medium large, and large). This grade level size was chosen as the operational definition of school size in this study because of the variations in school configurations, which might distort perceptions of school size. A K-12 unit school with 800 students is quite different from a stand-alone high school with 800 students. School size categories were derived by using the visual binning feature of SPSS, Version 15, which graphically depicts the natural break points in data distributions. The 85 11th grades in this study ranged from 40 students to 618 students, with a mean of 214 and a median size of 176 students. Binning these grade level sizes revealed that the small, medium small, and medium large categories were approximately equal in size, with the largest classification of grade level membership being only about half the size of any of the other categories.

Table 1 also shows the percentages of each basic type of school configuration within each school size category. It is interesting to note the wide variation in percentages of Title Ieligible schools that exist among school size categories. Medium large high schools show a very high percentage (86 percent), yet none of the largest schools were eligible. There was a gradual diminution in the percentage of students eligible for free or reduced price lunch as the size of the high schools increased. No discernible pattern exists in regard to the distribution of white and minority students served among the school size categories, other than a wide variation within each school size category.

\section{Research Question Two}

Research Question Two asked: To what extent do Alabama's public high schools vary in average daily attendance, number of pupils per computer in the classroom, number of pupils per computer with Internet access, percentage of teachers with a minimum of a master's degree, and percentage of highly qualified teachers, by school size? 
Table 2 (page 17) presents descriptive data on some selected school quality indicators, by school size category. All categories demonstrated a high percentage of average daily attendance, ranging from 94 percent to 95 percent. All school size categories had relatively good student-to-computer and student-to-computerwith-Internet-connection ratios (range $=4.7$ to 6.1). Almost all computers in all schools had Internet connections. Very little difference exists among school size categories in regard to the percentage of teachers who are highly qualified (range $=88$ percent to 94 percent) and who hold a master's degree or above (range $=$ 57 percent to 60 percent). For purposes of this study, Alabama's federally approved definition of "highly qualified teacher" was followed (Alabama State Department of Education, 2006).

\section{Research Question Three}

Research Question Three asked: To what extent do Alabama's public high schools vary in expenditures per pupil and local tax effort, by school size?

Table 3 (page 18) presents two key financial indicators, by school size category: expenditures per pupil and local district effort (measured in mills) to support the schools. Very little difference exists across size categories in regard to mean expenditures per pupil (range $=\$ 7,322$ to $\$ 7,829$ ). However, districts of the large high schools exert over twice the effort of those with small high schools (3.2 mills to 1.5 mills) and approximately 50 percent greater local effort than the districts of the medium size high schools.

\section{Research Question Four}

Research Question Four asked: To what extent do Alabama's public high schools vary in student performance on the math and reading portions of the AHSGE, by school size?

Tables 4 through 7 (pages 18-21) present the results of the 11 th grade student performance on the reading and math portions of the AHSGE from 2003-2004 to 2006-2007. Scores for regular education and special education students are analyzed separately, by school size category. The results are clear and consistent across the four years of scores analyzed. Scores for both groups of students were higher in math than in reading; scores for special education students were considerably lower than those of students without disabilities; scores in both subjects, for both groups, rose as the size of the school rose; and scores varied relatively little across the four-year period. There was strong variability of special education scores in both reading and math within each size classification. Cohen's D calculations were used to estimate the effect size differences in student test scores (2007 data) between the small and the large high schools. Effect sizes ranged from low ( $r=.18$, with approximately 14 percent overlap between the two groups) in reading for special education students to high $(r=.74$, with approximately 45 percent overlap between the two school size categories) in math for regular education students.

\section{Research Question Five}

Research Question Five asked: To what extent do the relationships among these variables vary by school size?

Table 8 (page 22) shows the relationships among key variables within the population of high schools in this study. A moderate negative relationship exists between school size and the percentage of students eligible for free or reduced price lunch $(r=-.437)$; smaller high schools serve less affluent populations, possibly because of their higher representation in Alabama's poor, rural areas. A moderate positive relationship $(r=.553)$ exists between school size and regular education student performance on the mathematics portion of the 2007 AHSGE. The percentage of highly qualified teachers in the school has a moderate positive $(r=.516)$ relationship with regular education students' reading scores on the 2007 AHSGE, but relatively little relationship to the other scores. Similarly, the percentage of teachers holding a master's degree or above had only weak relationships with test scores, as did stu- 
dent access to computers. The percentage of white students served in the high school showed moderate negative relationships to the percentage of students eligible for free and reduced price lunch $(r=-.718)$ and moderate positive relationships to the percentage of average daily attendance in the school (ADA) $(r=$ .595) and with the regular education reading scores on the 2007 AHSGE $(r=.526)$. Because there was so little variation in attendance rates, that variable had almost no relationship to test scores, other than a weak positive relationship $(r=.303)$ to regular education reading scores. Schools that were relatively effective in one test score category tended to be relatively successful in all categories. Moderate positive relationships ( $r=$ from .503 to .764) were found among test scores for reading and math for both regular and special education students on the 2007 AHSGE.

Table 9 (page 23) presents the relationships among the key variables with the percentage of students eligible for free and reduced price lunch held constant. It was important to remove the statistical effects of this variable because of its high autocorrelation with school size, percentage of average daily attendance, and the test results. This is an input factor which none of the schools can control. After removing the statistical effects of this variable, the relationships among the other variables shifted somewhat. School size exhibited low to moderate relationships with the math scores of both regular and special education students $(r=.422$ and .312 , respectively), but had virtually no relationship with any of the other variables. The percentage of highly qualified teachers in the high school showed a low to moderate positive relationship with the math scores of both regular education and special education students ( $r=.516$ and .350 , respectively), as did the percentage of teachers with a master's degree or above $(r=.342$ and .307 , respectively). The highest correlations were among the test scores themselves, with regular education reading scores having moderate positive relationships with all other scores.
In order to examine the variation both within and across school size categories, univariate analyses of variance were run (see Table 10, page 24). Clear differences were found across school size categories for both regular and special education math test results on the 2007 AHSGE. Post hoc tests (Bonferroni, Scheffe, and Tukey HSD) of differing degrees of conservatism were run on these results. Small high schools, which had the lowest test scores of all categories, differed $(p \leq .05)$ from large high schools in regular education reading and math. Small schools differed from all other size categories of schools in regular education math scores.

Univariate analyses of covariance were then run using the percentage of students eligible for free or reduced price lunch as the covariate. The results closely paralleled those of the univariate analyses of variance. Bonferronni posthoc tests found differences $(p \leq .05)$ between the small high schools and those of all other size categories for both regular and special education students on the math portion of the AHSGE. Differences were found only between the small and large high schools for the scores of special education students on this math test. Unlike the analysis of variance results, no significant differences in results were found among school size categories for the special education students on the reading portion of the exam.

\section{Research Question Six}

Research Question Six asked: To what extent do the school quality indicators (average daily attendance, number of pupils per computer in the classroom, number of pupils per computer with Internet access, percentage of teachers with a minimum of a master's degree, and percentage of highly qualified teachers) and school size predict student performance on the math and reading portions of the AHSGE?

Stepwise regression analyses were run to examine the relative contributions of school size, percentage of daily attendance, percentage of highly qualified teachers, and the percentage of teachers with a master's degree or above to pre- 
dicting student scores on the reading and math portions of the 2007 AHSGE. The percentage of students eligible for a free or reduced price lunch was intentionally omitted from these calculations. Stepwise regression was chosen because the order in which the predictors enter the model is determined mathematically, not by the researcher (Field, 2000, pp. 120-121). It also constantly reassesses the equation to determine if any redundant predictors can be removed. It is best used for building exploratory models, as was the case in this study. Table 11 (page 25) presents a summary of the results of those analyses. The relatively low adjusted $R^{2}$ figures for all analyses illustrate the restricted value of these variables for predicting student performance on these standardized examinations. School size was best at predicting math scores for regular education students, explaining approximately 30 percent of the variance in those scores, and reading scores for regular education students, explaining approximately 26 percent of the variance in those scores. The clustering of the Durbin-Watson statistics around 2.0 indicated that the residuals were relatively independent.

Table 12 (page 26) presents the results of similar stepwise regressions, with the addition of the variable related to the percentage of students eligible for free or reduced price lunch.

School size failed to enter the equation ( $p \leq$ .05 for entry) for the reading scores of either group of students. It was the primary variable to enter the equation for predicting both regular and special education math scores, but with respective adjusted $R^{2}$ s of only .306 and .153. Again, the clustering of the Durbin-Watson statistics around 2.0 indicated that the residuals were relatively independent.

\section{Research Question Seven}

Research Question Seven asked: To what extent do the relationships between student performance on the math and reading portions of the AHSGE and school size vary by the socioeconomic backgrounds of the students?

Table 13 (page 27) presents the results of Pearson Product Moment correlations between student performance on standardized examinations and the size of the 1lth grade in the school, for three categories (low percentage, medium percentage, and high percentage) of percentages of students qualified for free or reduced price lunch in the school. The categories were obtained using the binning feature of SPSS Version 15. As is illustrated in the table, grade level size related to student performance most strongly in those schools with the lowest percentage of students eligible for free or reduced price lunch and least strongly in those schools with the highest percentages. The relationships were higher for students in regular education programs than for those in special education programs.

\section{Conclusions}

The size of high schools in Alabama has relatively little relationship with 11 th grade student (both regular and special education) performance on the reading and math portions of the AHSGE. This supports the findings of five of the studies reviewed by Leithwood and Jantzi (2009), as well as the studies of Gardner et al. (2000) and Ornstein (1990). However, it is in contradiction to 14 of the studies reviewed by Leithwood and Jantzi and to the findings of Johnson (2006), Lee and Smith (1997), Schneider et al. (2007), and Werblow and Duesbery (2009). The correlations in this study between high school size and student performance on standardized tests were highest for students from higher socioeconomic backgrounds and for students not in special education programs, in contrast with Lee's (2000) findings.

Not surprisingly, the one variable that was most highly correlated (negatively) with test scores was the percentage of students eligible for free or reduced price lunch $(r=-.278$ to -.706). This was also negatively correlated to school size $(r=-.437)$. When this variable was held constant, the relationship between school size and test score results fell sharply $(r=.118$ to .422 ). These results were supported by the analyses of covariance and stepwise regressions. 
High schools' average daily attendance rates and pupil-to-computer (and computer with Internet connections) rates did not vary in accordance with school size, although students in moderately small high schools had considerably less access than their peers in other school size categories. Neither of these variables showed much relationship to student performance on standardized exams. Monk and Haller (1993) found that the certification of teachers in large schools was more closely aligned to the areas in which they taught than the certification of teachers in smaller schools, a finding partially supported by the data from this study, which showed that there were higher percentages of highly qualified teachers in Alabama's largest high schools. One interpretation of this result is that the increased breadth of curriculum offerings in larger schools allows a higher percentage of teachers to remain teaching exclusively in their fields of certification, whereas in smaller high schools, there may not be enough sections needed in a given subject area to occupy the teacher full-time, forcing that teacher to teach in another area in which he or she is not "highly qualified." However, there was no difference in the percentage of teachers with a master's degree or above across school size categories, nor was this a factor useful in predicting exam scores. The findings from this study supported the findings of Stiefel et al. (2000) that expenditures per pupil did not vary in accordance with school size. One interpretation might be that small variations in funding do not necessarily improve the quality of education in schools. Alabama's per-pupil expenditure differentials are relatively minor and do not permit large-scale reform differentials across schools.

Because the previous studies presented apparently conflicting results, it is not possible to interpret why Alabama's results agreed with some but contrasted with others. Perhaps part of the explanation lies in the varying definitions of small versus large high schools in each study and the variety of standardized tests used, as noted in the literature review.
In summary, there is little quality difference among Alabama's high schools relative to their size, and their size appears to have relatively little influence on their students' performance on the AHSGE, especially among the lower socioeconomic background students. It would be interesting to examine the extent to which the size of elementary and middle schools is related to quality and student performance, as learning at these levels has a direct influence on high school students' performance.

\section{References}

Alabama State Department of Education (ALSDE). (2004). The foundation program in Alabama. Retrieved on October 27, 2010 from http://www.alsde.edu/Academy/Finance/MO DULE12FOUNDATIONPROGRAMORIGIN .pdf

Alabama State Department of Education (ALSDE). (2006). High Objective Uniform State Standard of Evaluation (HOUSSE) Reinstated 2006. Retrieved October 27, 2010 from http://ww w.alsde.edu/html/HighlyQualified TeachersGuidanceandForms.asp

Alabama State Department of Education (ALSDE). (2007). Alabama High School Graduation Exam (AHSGE) overview. Retrieved on April 14, 2009, from http://www.alsde.edu/documents/91/Alabam a\%20High\%20School\%20Graduation\%20Ex am\%20Overview\%20Revised\%20July\%203\% 202007.pdf

Alabama State Department of Education (ALSDE). (2008). Annual data report: 2005-2006. Retrieved on April 14, 2009 , from http://www.alsde.edu/AllReportCards/06_An nual_Report.pdf

Editorial Projects in Education. (2009). Closing the graduation gap: Educational and economic conditions in America's largest cities. Bethesda, MD: Author.

Field, A. (2000). Discovering statistics using SPSS for Windows. Thousand Oaks, CA: Sage. 
Gardner, P. W., Ritblatt, S. N., \& Beatty, J. R. (2000). Academic achievement and parental school involvement as a function of high school size. High School Journal, 83(2), 2127.

Haller, E. J. (1992). High school size and student indiscipline: Another aspect of the school consolidation issue? Educational Evaluation and Policy Analysis, 14(2), 145156.

Howley, C. B. (2008). Don't supersize me: The relationship of construction cost to school enrollment in the U.S. Educational Planning, $17(2), 23-40$.

Iatarola, P., Schwartz, A. E., Stiefel, L., \& Chellman, C. C. (2008). Small schools, large districts: Small-school reform and New York City's students. Teachers College Record, 110(9), 1837-1878.

Jaffe-Walter, R. (2008). Negotiating mandates and memory: Inside a small schools network for immigrant youth. Teachers College Record, 110(9), 2040-2066.

Jencks, C., Smith, M., Aland, H., Bane, M. J., Cohen, D., Gintis, H., Heyns, B., \& Michelson, S. (1972). Inequality: A reassessment of the effect of family and schooling in America. New York: Harper \& Row.

Johnson, J. (2006). More doesn't mean better. Randolph, VT: The Rural School and Community Trust Policy Program.

Kafka, J. (2008). Thinking big about getting small: An ideological genealogy of smallschool reform. Teachers College Record, 110(9), 1802-1836.

Kahne, J. E., Sporte, S. E., de la Torre, M., \& Easton, J. Q. (2008). Small high schools on a larger scale: The impact of school conversions in Chicago. Educational Evaluation and Policy Analysis, 30(3), 281-315.

Kleinert, E. J. (1969). Effects of high school size on student activity participation. NASSP Bulletin, 53(335), 34-46.

Lee, V. E. (2000). Using hierarchical linear modeling to study social contexts: The case of school effects. Educational Psychologist, 35(2), 125-141.
Lee, V. E., \& Burkam, D. T. (2003). Dropping out of high school: The role of school organization and structure. American Educational Research Journal, 40(2), 353-393.

Lee, V. E., Smerdon, B. A., Alfeld-Liro, C., \& Brown, S. L. (2000). Inside large and small high schools: Curriculum and social relations. Educational Evaluation and Policy Analysis, 22(2), 147-171.

Lee, V. E., \& Smith, J. B. (1997). High school size; Which works best and for whom? Educational Evaluation and Policy Analysis, 19(3), 205-227.

Leithwood, K., \& Jantzi, D. (2009). A review of empirical evidence about school size effects: A policy perspective. Review of Educational Research, 79(1), 464-490.

Maroulis, S., \& Gomez, L. M. (2008). Does "connectedness" matter? Evidence from a social network analysis within a smallschool reform. Teachers College Record, 110(9), 1901-1929.

McQuillan, P. J. (2008). Small-school reform through the lens of complexity theory: It's "good to think with." Teachers College Record, 110(9), 1772-1801.

Monk, D. H., \& Haller, E. J. (1993). Predictors of high school academic course offerings: The role of school size. American Educational Research Journal, 30(1), 3-21.

National Center for Educational Statistics. (1995). National Education Longitudinal Study of 1988: Psychometric report for the NELS:88 base year through second followup (NCES-95-382). Washington, DC: U.S. Department of Education, Office of Educational Research and Improvement.

National Center for Educational Statistics. (2009). Digest of education statistics. Washington, DC: Author. Retrieved from http://nces.ed.gov/programs/digest/d.09/table s/dt 09-095.asp

National Opinion Research Center. (1987). High School and Beyond 1980 senior cohort follow-up (1986) data file user's manual. Washington, DC: Center for Educational Statistics. 
Ornstein, A. C. (1990). How BIG should schools and districts be? Education Digest, 56(2), 44-47.

Pittman, R. B., \& Haughwout, P. (1987). Influence of high school size on dropout rate. Educational Evaluation and Policy Analysis, 9(4), 337-343.

Ravitch, D. (2010). The death and life of the great American school system: How testing and choice are undermining education. New York: Basic Books.

Ready, D. D., \& Lee, V. E. (2008). Choice, equity, and the schools-within-schools reform. Teachers College Record, 110(9), 1930-1958.

Schneider, B., Wyse, A. E., \& Kessler, V. (2007). Is small really better? Testing some assumptions about high school size. In D. Ravitch (Ed.), Brookings Papers on Education Policy, 2006/2007 (pp. 15-47). Washington, DC: Brookings Institution Press.

Schoggen, P., \& Schoggen, M. (1988). Student voluntary participation and high school size. Journal of Educational Research, 81(5), 288293.

Scott, L. A., Ingels, S. J., Sehra, S., Taylor, J. R., \& Jergovic, D. (1996, March). High school effectiveness study: Data file user's manual (National Educational Longitudinal Study of 1988). Washington, DC: U.S. Department of Education, Office of Educational Research and Improvement, National Center for Education Statistics.

Semel, S. F., \& Sadovnik, A. R. (2008). The contemporary small-school movement: Lessons from the history of progressive education. Teachers College Record, 110(9), 1744-1771.

Shear, L., Means, B., Mitchell, K., House, A., Gorges, T., Joshi, A., Smerdon, B., \& Shkolnik, J. (2008). Contrasting paths to smallschool reform: Results of a 5-year evaluation of the Bill and Melinda Gates Foundation's National High Schools Initiative. Teachers College Record, 110(9), 1986-2039.
Stiefel, L., Berne, R., Iatarola, P., \& Fruchter, N. (2000). High school size: Effects on budgets and performance in New York City. Educational Evaluation and Policy Analysis, 22(1), 27-39.

U.S. Department of Education. (2005). A profile of the American high school sophomore in 2002: Initial results of the base year of the Educational Longitudinal Study of 2002. Washington, DC: National Center for Educational Statistics (NCES 2005-338).

Werblow, J., \& Duesbery, L. (2009). The impact of high school size on math achievement and dropout rate. Chapel Hill, NC: The University of North Carolina Press.

Wyse, A. E., Keesler, V, \& Schneider, B. (2008). Assessing the effects of small school size on mathematics achievement: A propensity score-matching approach. Teachers College Record, 110(9), 1879-1900. 
Table 1: Demographic Characteristics of Alabama's High Schools, by Size Category (2006-2007 Data)

\begin{tabular}{|c|c|c|c|c|c|}
\hline $\begin{array}{l}\text { Demographic } \\
\text { Characteristic }\end{array}$ & & $\begin{array}{l}\text { Small High } \\
\text { Schools } \\
(\mathrm{N}=29) \\
\mathrm{N} \text { or } \%\end{array}$ & $\begin{array}{l}\text { Medium Small } \\
\text { High Schools } \\
(\mathrm{N}=24)\end{array}$ & $\begin{array}{l}\text { Medium Large } \\
\text { High Schools } \\
(\mathrm{N}=21)\end{array}$ & $\begin{array}{l}\text { Large High } \\
\text { Schools } \\
(\mathrm{N}=11)\end{array}$ \\
\hline $\begin{array}{l}\text { Number of Pupils } \\
\text { in the 11th Grade }\end{array}$ & $\begin{array}{l}\text { Mean } \\
\text { SD } \\
\text { Median } \\
\text { Range }\end{array}$ & $\begin{array}{l}88 \\
21.6 \\
89 \\
40-120\end{array}$ & $\begin{array}{l}177 \\
33.4 \\
175 \\
124-240\end{array}$ & $\begin{array}{l}303 \\
34.6 \\
304 \\
250-370\end{array}$ & $\begin{array}{l}461 \\
78.5 \\
439 \\
372-618\end{array}$ \\
\hline $\begin{array}{l}\text { School Configura- } \\
\text { tions, by \% } \\
\text { Grades K-12 }\end{array}$ & & $45 \%$ & - & - & - \\
\hline Grades 7-12 & & $38 \%$ & $21 \%$ & - & - \\
\hline Grades 9-12 & & $17 \%$ & $79 \%$ & $100 \%$ & $100 \%$ \\
\hline $\begin{array}{l}\text { \% of Schools Title I } \\
\text { Eligible }\end{array}$ & & $34 \%$ & $17 \%$ & $86 \%$ & $0 \%$ \\
\hline $\begin{array}{l}\text { Mean \% of Students } \\
\text { Qualified for Free } \\
\text { or Reduced Price } \\
\text { Lunch }\end{array}$ & $\begin{array}{l}\text { Mean } \\
\text { SD } \\
\text { Median } \\
\text { Range }\end{array}$ & $\begin{array}{l}48 \% \\
17.5 \% \\
48 \% \\
19-86 \%\end{array}$ & $\begin{array}{l}46 \% \\
22.7 \% \\
41 \% \\
11-82 \%\end{array}$ & $\begin{array}{l}35 \% \\
18.7 \% \\
35 \% \\
8-77 \%\end{array}$ & $\begin{array}{l}22 \% \\
15.8 \% \\
16 \% \\
3-54 \%\end{array}$ \\
\hline $\begin{array}{l}\text { \% of White Stu- } \\
\text { dents }\end{array}$ & $\begin{array}{l}\text { Mean } \\
\text { SD } \\
\text { Median } \\
\text { Range }\end{array}$ & $\begin{array}{l}75 \% \\
26.8 \% \\
85 \% \\
0-100 \%\end{array}$ & $\begin{array}{l}53 \% \\
37.6 \% \\
67 \% \\
0-97 \%\end{array}$ & $\begin{array}{l}62 \% \\
27.8 \% \\
69 \% \\
0-92 \%\end{array}$ & $\begin{array}{l}68 \% \\
17.4 \% \\
73 \% \\
29-87 \%\end{array}$ \\
\hline
\end{tabular}




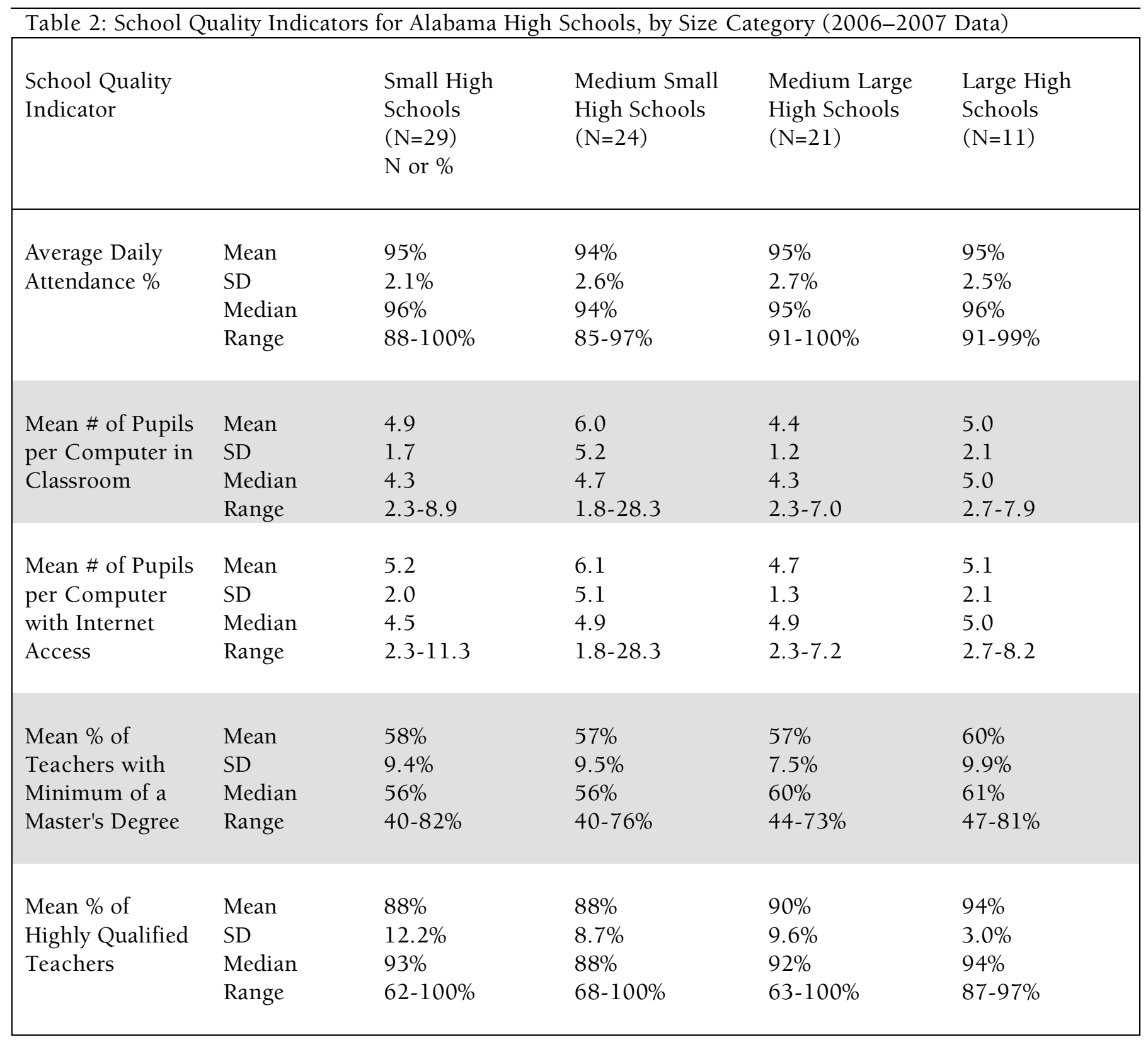




\begin{tabular}{|c|c|c|c|c|c|}
\hline Financial Indicator & & $\begin{array}{l}\text { Small High } \\
\text { Schools } \\
(\mathrm{N}=29)\end{array}$ & $\begin{array}{l}\text { Medium Small } \\
\text { High Schools } \\
(\mathrm{N}=24)\end{array}$ & $\begin{array}{l}\text { Medium Large } \\
\text { High Schools } \\
(\mathrm{N}=21)\end{array}$ & $\begin{array}{l}\text { Large High } \\
\text { Schools } \\
(\mathrm{N}=11)\end{array}$ \\
\hline $\begin{array}{l}\text { Mean Expenditures } \\
\text { per Pupil }\end{array}$ & $\begin{array}{l}\text { Mean } \\
\text { SD } \\
\text { Median } \\
\text { Range }\end{array}$ & $\begin{array}{l}\$ 7,322 \\
\$ 484 \\
\$ 7,253 \\
\$ 6,519-\$ 8,581\end{array}$ & $\begin{array}{l}\$ 7,555 \\
\$ 883 \\
\$ 7,220 \\
\$ 6,587- \\
\$ 10,694\end{array}$ & $\begin{array}{l}\$ 7,829 \\
\$ 536 \\
\$ 7,832 \\
\$ 6,920-\$ 8,678\end{array}$ & $\begin{array}{l}\$ 7,730 \\
\$ 880 \\
\$ 7,339 \\
\$ 6,914-\$ 9,125\end{array}$ \\
\hline $\begin{array}{l}\text { Mean Local District } \\
\text { Millage Rate (Cate- } \\
\text { gory) }\end{array}$ & $\begin{array}{l}\text { Mean } \\
\text { SD } \\
\text { Median } \\
\text { Range }\end{array}$ & $\begin{array}{l}1.5 \\
1.2 \\
2.0 \\
0-4\end{array}$ & $\begin{array}{l}2.2 \\
1.3 \\
2.0 \\
0-4\end{array}$ & $\begin{array}{l}2.1 \\
1.0 \\
2.0 \\
1-4\end{array}$ & $\begin{array}{l}3.2 \\
0.9 \\
4.0 \\
1-4\end{array}$ \\
\hline
\end{tabular}

Table 4: 11th Grade Student Mean Passing Percentages on the 2004 Alabama High School Graduation Examination, by School Size Category

\begin{tabular}{|c|c|c|c|c|c|}
\hline $\begin{array}{l}\text { Mean Percentile } \\
\text { Performance }\end{array}$ & & $\begin{array}{l}\text { Small High } \\
\text { Schools } \\
(\mathrm{N}=29)\end{array}$ & $\begin{array}{l}\text { Medium Small } \\
\text { High Schools } \\
(\mathrm{N}=24)\end{array}$ & $\begin{array}{l}\text { Medium Large } \\
\text { High Schools } \\
(\mathrm{N}=21)\end{array}$ & $\begin{array}{l}\text { Large High } \\
\text { Schools } \\
(\mathrm{N}=11)\end{array}$ \\
\hline $\begin{array}{l}\text { Reading } \\
\text { (Regular Educa- } \\
\text { tion) }\end{array}$ & $\begin{array}{l}\text { Mean } \\
\text { SD } \\
\text { Median } \\
\text { Range }\end{array}$ & $\begin{array}{l}81 \% \\
9.6 \% \\
83 \% \\
55-100 \%\end{array}$ & $\begin{array}{l}86 \% \\
8.0 \% \\
86 \% \\
63-98 \%\end{array}$ & $\begin{array}{l}91 \% \\
5.3 \% \\
94 \% \\
81-99 \%\end{array}$ & $\begin{array}{l}95 \% \\
3.6 \% \\
95 \% \\
88-99 \%\end{array}$ \\
\hline $\begin{array}{l}\text { Math } \\
\text { (Regular Educa- } \\
\text { tion) }\end{array}$ & $\begin{array}{l}\text { Mean } \\
\text { SD } \\
\text { Median } \\
\text { Range }\end{array}$ & $\begin{array}{l}79 \% \\
8.8 \% \\
80 \% \\
57-92 \%\end{array}$ & $\begin{array}{l}76 \% \\
12.7 \% \\
78 \% \\
55-98 \%\end{array}$ & $\begin{array}{l}85 \% \\
10.5 \% \\
88 \% \\
59-97 \%\end{array}$ & $\begin{array}{l}91 \% \\
6.9 \% \\
90 \% \\
75-97 \%\end{array}$ \\
\hline $\begin{array}{l}\text { Reading } \\
\text { (Special Educa- } \\
\text { tion) }\end{array}$ & $\begin{array}{l}\text { Mean } \\
\text { SD } \\
\text { Median } \\
\text { Range }\end{array}$ & $\begin{array}{l}26 \% \\
15.7 \% \\
24 \% \\
0-54 \%\end{array}$ & $\begin{array}{l}39 \% \\
21.7 \% \\
36 \% \\
0-88 \%\end{array}$ & $\begin{array}{l}38 \% \\
19.3 \% \\
40 \% \\
8-77 \%\end{array}$ & $\begin{array}{l}56 \% \\
20.7 \% \\
62 \% \\
23-82 \%\end{array}$ \\
\hline $\begin{array}{l}\text { Math } \\
\text { (Special Educa- } \\
\text { tion) }\end{array}$ & $\begin{array}{l}\text { Mean } \\
\text { SD } \\
\text { Median } \\
\text { Range }\end{array}$ & $\begin{array}{l}19 \% \\
15.4 \% \\
15 \% \\
0-46 \%\end{array}$ & $\begin{array}{l}28 \% \\
20.8 \% \\
25 \% \\
0-80 \%\end{array}$ & $\begin{array}{l}30 \% \\
18.6 \% \\
24 \% \\
0-69 \%\end{array}$ & $\begin{array}{l}43 \% \\
25.5 \% \\
38 \% \\
0-82 \%\end{array}$ \\
\hline
\end{tabular}




\begin{tabular}{|c|c|c|c|c|c|}
\hline $\begin{array}{l}\text { Mean Percentile } \\
\text { Performance }\end{array}$ & & $\begin{array}{l}\text { Small High } \\
\text { Schools } \\
(\mathrm{N}=29)\end{array}$ & $\begin{array}{l}\text { Medium Small } \\
\text { High Schools } \\
(\mathrm{N}=24)\end{array}$ & $\begin{array}{l}\text { Medium Large } \\
\text { High Schools } \\
(\mathrm{N}=21)\end{array}$ & $\begin{array}{l}\text { Large High } \\
\text { Schools } \\
(\mathrm{N}=11)\end{array}$ \\
\hline $\begin{array}{l}\text { Reading } \\
\text { (Regular Educa- } \\
\text { tion) }\end{array}$ & $\begin{array}{l}\text { Mean } \\
\text { SD } \\
\text { Median } \\
\text { Range }\end{array}$ & $\begin{array}{l}85 \% \\
8.1 \% \\
87 \% \\
61-96 \%\end{array}$ & $\begin{array}{l}89 \% \\
7.0 \% \\
90 \% \\
63-98 \%\end{array}$ & $\begin{array}{l}91 \% \\
6.2 \% \\
93 \% \\
78-99 \%\end{array}$ & $\begin{array}{l}96 \% \\
2.4 \% \\
96 \% \\
92-99 \%\end{array}$ \\
\hline $\begin{array}{l}\text { Math } \\
\text { (Regular Educa- } \\
\text { tion) }\end{array}$ & $\begin{array}{l}\text { Mean } \\
\text { SD } \\
\text { Median } \\
\text { Range }\end{array}$ & $\begin{array}{l}74 \% \\
10.7 \% \\
74 \% \\
51-90 \%\end{array}$ & $\begin{array}{l}79 \% \\
11.6 \% \\
82 \% \\
53-98 \%\end{array}$ & $\begin{array}{l}84 \% \\
10.7 \% \\
92 \% \\
69-98 \%\end{array}$ & $\begin{array}{l}91 \% \\
7.3 \% \\
93 \% \\
75-99 \%\end{array}$ \\
\hline $\begin{array}{l}\text { Reading } \\
\text { (Special Educa- } \\
\text { tion) }\end{array}$ & $\begin{array}{l}\text { Mean } \\
\text { SD } \\
\text { Median } \\
\text { Range }\end{array}$ & $\begin{array}{l}25 \% \\
14.8 \% \\
25 \% \\
0-70 \%\end{array}$ & $\begin{array}{l}33 \% \\
13.5 \% \\
31 \% \\
11-65 \%\end{array}$ & $\begin{array}{l}32 \% \\
18.8 \% \\
38 \% \\
3-68 \%\end{array}$ & $\begin{array}{l}53 \% \\
18.5 \% \\
60 \% \\
30-80 \%\end{array}$ \\
\hline $\begin{array}{l}\text { Math } \\
\text { (Special Educa- } \\
\text { tion) }\end{array}$ & $\begin{array}{l}\text { Mean } \\
\text { SD } \\
\text { Median } \\
\text { Range }\end{array}$ & $\begin{array}{l}18 \% \\
14.0 \% \\
18 \% \\
0-70 \%\end{array}$ & $\begin{array}{l}26 \% \\
13.8 \% \\
23 \% \\
4-53 \%\end{array}$ & $\begin{array}{l}29 \% \\
16.8 \% \\
27 \% \\
3-70 \%\end{array}$ & $\begin{array}{l}40 \% \\
16.4 \% \\
40 \% \\
19-72 \%\end{array}$ \\
\hline
\end{tabular}




\begin{tabular}{|c|c|c|c|c|c|}
\hline $\begin{array}{l}\text { Mean Percentile } \\
\text { Performance }\end{array}$ & & $\begin{array}{l}\text { Small High } \\
\text { Schools } \\
(\mathrm{N}=29)\end{array}$ & $\begin{array}{l}\text { Medium Small } \\
\text { High Schools } \\
(\mathrm{N}=24)\end{array}$ & $\begin{array}{l}\text { Medium Large } \\
\text { High Schools } \\
(\mathrm{N}=21)\end{array}$ & $\begin{array}{l}\text { Large High } \\
\text { Schools } \\
(\mathrm{N}=11)\end{array}$ \\
\hline $\begin{array}{l}\text { Reading } \\
\text { (Regular Educa- } \\
\text { tion) }\end{array}$ & $\begin{array}{l}\text { Mean } \\
\text { SD } \\
\text { Median } \\
\text { Range }\end{array}$ & $\begin{array}{l}85 \% \\
7.8 \% \\
86 \% \\
56-99 \%\end{array}$ & $\begin{array}{l}88 \% \\
6.6 \% \\
89 \% \\
71-99 \%\end{array}$ & $\begin{array}{l}91 \% \\
6.0 \% \\
93 \% \\
74-99 \%\end{array}$ & $\begin{array}{l}95 \% \\
3.7 \% \\
96 \% \\
88-100 \%\end{array}$ \\
\hline $\begin{array}{l}\text { Math } \\
\text { (Regular Educa- } \\
\text { tion) }\end{array}$ & $\begin{array}{l}\text { Mean } \\
\text { SD } \\
\text { Median } \\
\text { Range }\end{array}$ & $\begin{array}{l}77 \% \\
10.6 \% \\
78 \% \\
43-91 \%\end{array}$ & $\begin{array}{l}84 \% \\
10.8 \% \\
85 \% \\
57-99 \%\end{array}$ & $\begin{array}{l}89 \% \\
7.7 \% \\
92 \% \\
69-98 \%\end{array}$ & $\begin{array}{l}93 \% \\
5.9 \% \\
95 \% \\
82-100 \%\end{array}$ \\
\hline $\begin{array}{l}\text { Reading } \\
\text { (Special Educa- } \\
\text { tion) }\end{array}$ & $\begin{array}{l}\text { Mean } \\
\text { SD } \\
\text { Median } \\
\text { Range }\end{array}$ & $\begin{array}{l}29 \% \\
13.6 \% \\
28 \% \\
0-55 \%\end{array}$ & $\begin{array}{l}35 \% \\
15.4 \% \\
32 \% \\
0-79 \%\end{array}$ & $\begin{array}{l}35 \% \\
17.7 \% \\
38 \% \\
3-68 \%\end{array}$ & $\begin{array}{l}44 \% \\
20.7 \% \\
47 \% \\
8-79 \%\end{array}$ \\
\hline $\begin{array}{l}\text { Math } \\
\text { (Special Educa- } \\
\text { tion) }\end{array}$ & $\begin{array}{l}\text { Mean } \\
\text { SD } \\
\text { Median } \\
\text { Range }\end{array}$ & $\begin{array}{l}27 \% \\
13.4 \% \\
25 \% \\
4-57 \%\end{array}$ & $\begin{array}{l}32 \% \\
17.8 \% \\
28 \% \\
0-71 \%\end{array}$ & $\begin{array}{l}32 \% \\
14.5 \% \\
36 \% \\
3-58 \%\end{array}$ & $\begin{array}{l}41 \% \\
19.5 \% \\
38 \% \\
18-79 \%\end{array}$ \\
\hline
\end{tabular}


Table 7: 11th Grade Student Mean Passing Percentages on the 2007 Alabama High School Graduation Examination, by School Size Category

\begin{tabular}{|c|c|c|c|c|c|}
\hline $\begin{array}{l}\text { Mean Percentile } \\
\text { Performance }\end{array}$ & & $\begin{array}{l}\text { Small High } \\
\text { Schools } \\
(\mathrm{N}=29)\end{array}$ & $\begin{array}{l}\text { Medium Small } \\
\text { High Schools } \\
(\mathrm{N}=24)\end{array}$ & $\begin{array}{l}\text { Medium Large } \\
\text { High Schools } \\
(\mathrm{N}=21)\end{array}$ & $\begin{array}{l}\text { Large High } \\
\text { Schools } \\
(\mathrm{N}=11)\end{array}$ \\
\hline $\begin{array}{l}\text { Reading } \\
\text { (Regular Educa- } \\
\text { tion) }\end{array}$ & $\begin{array}{l}\text { Mean } \\
\text { SD } \\
\text { Median } \\
\text { Range }\end{array}$ & $\begin{array}{l}85 \% \\
8.0 \% \\
87 \% \\
65-98 \%\end{array}$ & $\begin{array}{l}88 \% \\
6.6 \% \\
89 \% \\
70-97 \%\end{array}$ & $\begin{array}{l}90 \% \\
5.5 \% \\
91 \% \\
73-97 \%\end{array}$ & $\begin{array}{l}93 \% \\
5.2 \% \\
94 \% \\
80-99 \%\end{array}$ \\
\hline $\begin{array}{l}\text { Math } \\
\text { (Regular Educa- } \\
\text { tion) }\end{array}$ & $\begin{array}{l}\text { Mean } \\
\text { SD } \\
\text { Median } \\
\text { Range }\end{array}$ & $\begin{array}{l}79 \% \\
8.0 \% \\
77 \% \\
62-98 \%\end{array}$ & $\begin{array}{l}86 \% \\
11.2 \% \\
88 \% \\
55-99 \%\end{array}$ & $\begin{array}{l}93 \% \\
7.2 \% \\
95 \% \\
69-99 \%\end{array}$ & $\begin{array}{l}94 \% \\
5.5 \% \\
94 \% \\
81-100 \%\end{array}$ \\
\hline $\begin{array}{l}\text { Reading } \\
\text { (Special Educa- } \\
\text { tion) }\end{array}$ & $\begin{array}{l}\text { Mean } \\
\text { SD } \\
\text { Median } \\
\text { Range }\end{array}$ & $\begin{array}{l}27 \% \\
14.0 \% \\
25 \% \\
0-57 \%\end{array}$ & $\begin{array}{l}35 \% \\
15.4 \% \\
33 \% \\
5-71 \%\end{array}$ & $\begin{array}{l}32 \% \\
12.8 \% \\
32 \% \\
10-57 \%\end{array}$ & $\begin{array}{l}47 \% \% \\
18.9 \% \\
44 \% \\
15-77 \%\end{array}$ \\
\hline $\begin{array}{l}\text { Math } \\
\text { (Special Educa- } \\
\text { tion) }\end{array}$ & $\begin{array}{l}\text { Mean } \\
\text { SD } \\
\text { Median } \\
\text { Range }\end{array}$ & $\begin{array}{l}25 \% \\
15.6 \% \\
23 \% \\
8-73 \%\end{array}$ & $\begin{array}{l}36 \% \\
22.1 \% \\
31 \% \\
8-83 \%\end{array}$ & $\begin{array}{l}37 \% \\
17.2 \% \\
37 \% \\
10-71 \%\end{array}$ & $\begin{array}{l}51 \% \\
18.9 \% \\
46 \% \\
25-82 \%\end{array}$ \\
\hline
\end{tabular}


Table 8: Key Correlations among Variables Related to High School Size

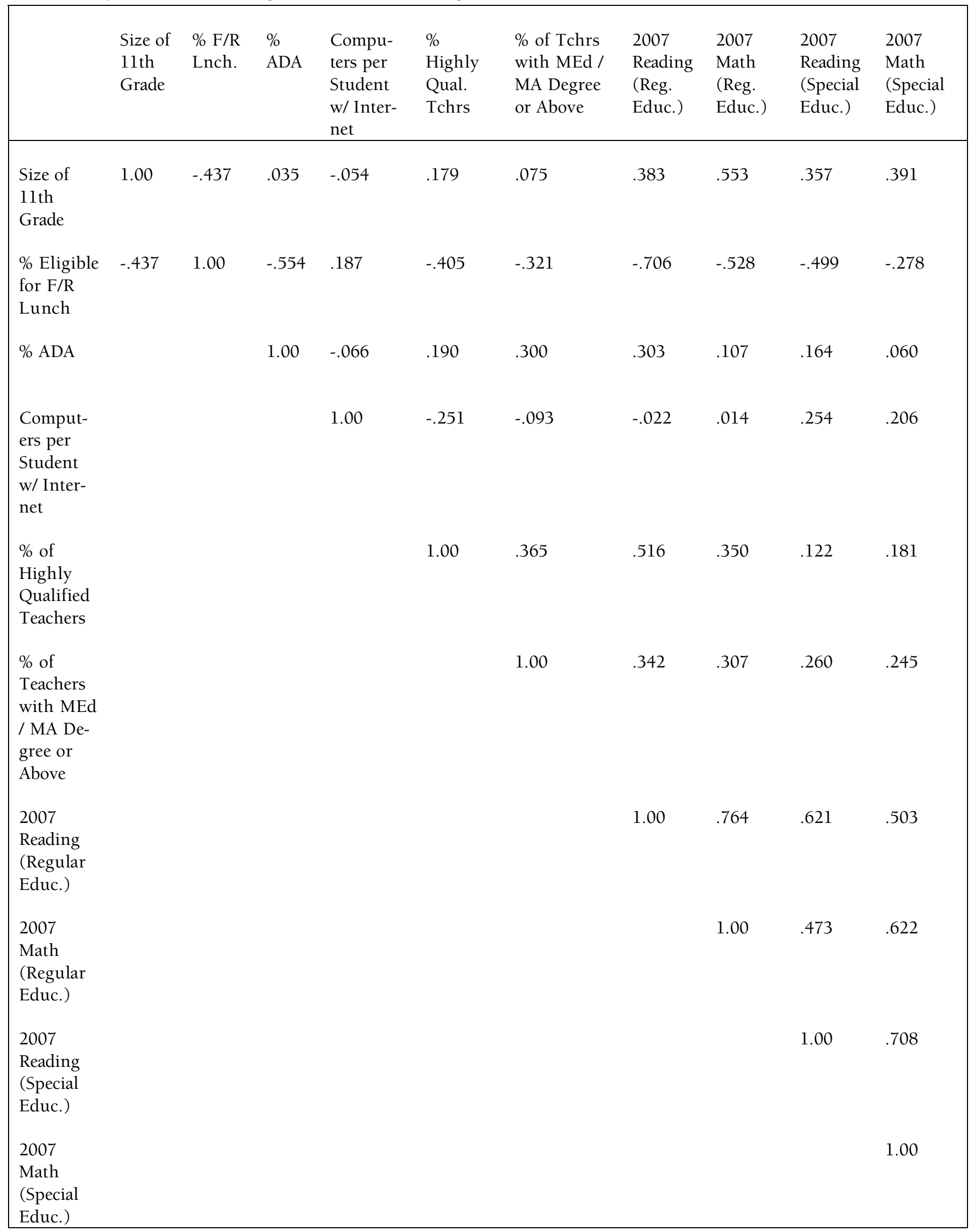




\begin{tabular}{|c|c|c|c|c|c|c|c|c|c|}
\hline & $\begin{array}{l}\text { Size of } \\
11 \text { th } \\
\text { Grade }\end{array}$ & $\% \mathrm{ADA}$ & $\begin{array}{l}\text { Computers } \\
\text { per Student } \\
\text { w/ Internet }\end{array}$ & $\begin{array}{l}\text { \% Highly } \\
\text { Qualified } \\
\text { Teachers }\end{array}$ & $\begin{array}{l}\% \text { of Tchrs } \\
\text { with MEd / } \\
\text { MA Degree } \\
\text { or Above }\end{array}$ & $\begin{array}{l}2007 \\
\text { Reading } \\
\text { (Reg. } \\
\text { Educ.) }\end{array}$ & $\begin{array}{l}2007 \\
\text { Math } \\
\text { (Reg. } \\
\text { Educ.) }\end{array}$ & $\begin{array}{l}2007 \\
\text { Reading } \\
\text { (Special } \\
\text { Educ.) }\end{array}$ & $\begin{array}{l}2007 \\
\text { Math } \\
\text { (Special } \\
\text { Educ.) }\end{array}$ \\
\hline $\begin{array}{l}\text { Size of } \\
\text { 11th Grade }\end{array}$ & 1.00 & -.035 & -.061 & .002 & .075 & .118 & .422 & .178 & .312 \\
\hline$\%$ ADA & & 1.00 & -.067 & .190 & .300 & .303 & .107 & .164 & .060 \\
\hline $\begin{array}{l}\text { Computers } \\
\text { per Student } \\
\text { w/ Internet }\end{array}$ & & & 1.00 & -.247 & -.083 & -.016 & .018 & .247 & .201 \\
\hline $\begin{array}{l}\% \text { of } \\
\text { Highly } \\
\text { Qualified } \\
\text { Teachers }\end{array}$ & & & & 1.00 & .365 & .516 & .350 & .122 & .181 \\
\hline $\begin{array}{l}\% \text { of } \\
\text { Teachers } \\
\text { with Mas- } \\
\text { ter's Degree } \\
\text { or Above }\end{array}$ & & & & & 1.00 & .342 & .307 & .260 & .245 \\
\hline $\begin{array}{l}2007 \text { Read- } \\
\text { ing } \\
\text { (Regular } \\
\text { Educ.) }\end{array}$ & & & & & & 1.00 & .764 & .621 & .503 \\
\hline $\begin{array}{l}2007 \text { Math } \\
\text { (Regular } \\
\text { Educ.) }\end{array}$ & & & & & & & 1.00 & .473 & .622 \\
\hline $\begin{array}{l}2007 \text { Read- } \\
\text { ing (Spe- } \\
\text { cial Educ.) }\end{array}$ & & & & & & & & 1.00 & .708 \\
\hline $\begin{array}{l}2007 \text { Math } \\
\text { (Special } \\
\text { Educ.) }\end{array}$ & & & & & & & & & 1.00 \\
\hline
\end{tabular}




\begin{tabular}{|c|c|c|c|c|c|c|}
\hline Examination & $\begin{array}{l}\text { Source of } \\
\text { Variance }\end{array}$ & df & $\begin{array}{l}\text { Sum of } \\
\text { Squares }\end{array}$ & Mean Square & $\mathrm{F}$ & Sig. \\
\hline \multirow[t]{2}{*}{$\begin{array}{l}\text { Reading-Regular } \\
\text { Ed. }\end{array}$} & $\begin{array}{l}\text { Between } \\
\text { Groups }\end{array}$ & 3 & 636.30 & 212.10 & 4.64 & .005 \\
\hline & $\begin{array}{l}\text { Within } \\
\text { Groups }\end{array}$ & 81 & 3703.64 & 45.72 & & \\
\hline \multirow[t]{2}{*}{$\begin{array}{l}\text { Reading-Special } \\
\text { Ed. }\end{array}$} & $\begin{array}{l}\text { Between } \\
\text { Groups }\end{array}$ & 3 & 3260.16 & 1986.72 & 4.96 & .003 \\
\hline & $\begin{array}{l}\text { Within } \\
\text { Groups }\end{array}$ & 81 & 17739.02 & 219.00 & & \\
\hline \multirow[t]{2}{*}{$\begin{array}{l}\text { Math-Regular } \\
\text { Ed. }\end{array}$} & $\begin{array}{l}\text { Between } \\
\text { Groups }\end{array}$ & 3 & 5902.24 & 1967.41 & 5.80 & .001 \\
\hline & $\begin{array}{l}\text { Within } \\
\text { Groups }\end{array}$ & 81 & 27497.68 & 339.48 & & \\
\hline \multirow[t]{2}{*}{ Math-Special Ed. } & $\begin{array}{l}\text { Between } \\
\text { Groups }\end{array}$ & 3 & 3148.91 & 1049.64 & 14.13 & .000 \\
\hline & $\begin{array}{l}\text { Within } \\
\text { Groups }\end{array}$ & 81 & 6016.98 & 74.28 & & \\
\hline
\end{tabular}


Table 11: Summary Results of Stepwise Regression Analyses on 2007 Examination Scores, Without Considering the Percentage of Students Eligible for Free and Reduced Price Lunch

\begin{tabular}{|c|c|c|c|c|}
\hline Test/Student Group & $\begin{array}{l}\text { Variables Entered, } \\
\text { in Order } \\
(=<.05 \text { to enter })\end{array}$ & Adjusted $\mathrm{R}^{2}$ & $\mathrm{R}^{2}$ Change & $\begin{array}{l}\text { Durbin-Watson } \\
\text { Statistic }\end{array}$ \\
\hline \multirow{3}{*}{$\begin{array}{l}\text { Reading-Regular } \\
\text { Education }\end{array}$} & \% Highly Qualified & .257 & .266 & 2.12 \\
\hline & School Size & .338 & .088 & \\
\hline & $\% \mathrm{ADA}$ & .385 & .053 & \\
\hline \multirow{2}{*}{$\begin{array}{l}\text { Reading-Special } \\
\text { Education }\end{array}$} & School Size & .117 & .127 & 1.94 \\
\hline & $\%$ Teachers w/ M+ & .162 & .055 & \\
\hline \multirow{3}{*}{$\begin{array}{l}\text { Math-Regular } \\
\text { Education }\end{array}$} & School Size & .298 & .306 & 1.92 \\
\hline & $\%$ Teachers w/ M+ & .362 & .071 & \\
\hline & \% Highly Qualified & .384 & .029 & \\
\hline \multirow{2}{*}{$\begin{array}{l}\text { Math-Special } \\
\text { Education }\end{array}$} & School Size & .143 & .153 & 1.93 \\
\hline & $\%$ Teachers M+ & .180 & .047 & \\
\hline
\end{tabular}


Table 12: Summary Results of Stepwise Regression Analyses on 2007 Examination Scores, Considering the Percentage of Students Eligible for Free and Reduced Price Lunch

\begin{tabular}{|c|c|c|c|c|}
\hline Test/Student Group & $\begin{array}{l}\text { Variables Entered, } \\
\text { in Order } \\
(=<.05 \text { to enter })\end{array}$ & Adjusted $\mathrm{R}^{2}$ & $\mathrm{R}^{2}$ Change & $\begin{array}{l}\text { Durbin-Watson } \\
\text { Statistic }\end{array}$ \\
\hline \multirow[t]{2}{*}{$\begin{array}{l}\text { Reading-Regular } \\
\text { Education }\end{array}$} & $\begin{array}{l}\text { \% Eligible for Free } \\
\text { or Reduced Price } \\
\text { Lunch }\end{array}$ & .492 & .498 & 1.91 \\
\hline & \% Highly Qualified & .551 & .063 & \\
\hline $\begin{array}{l}\text { Reading-Special } \\
\text { Education }\end{array}$ & $\begin{array}{l}\text { \% Eligible for Free } \\
\text { or Reduced Price } \\
\text { Lunch }\end{array}$ & .240 & .249 & 1.91 \\
\hline \multirow{3}{*}{$\begin{array}{l}\text { Math-Regular } \\
\text { Education }\end{array}$} & School Size & .298 & .306 & 1.95 \\
\hline & $\begin{array}{l}\text { \% Eligible for Free } \\
\text { or Reduced Price } \\
\text { Lunch }\end{array}$ & .393 & .102 & \\
\hline & $\%$ Teachers w/ M+ & .417 & .030 & \\
\hline \multirow{2}{*}{$\begin{array}{l}\text { Math-Special } \\
\text { Education }\end{array}$} & School Size & .143 & .153 & 1.93 \\
\hline & $\%$ Teachers M+ & .180 & .047 & \\
\hline
\end{tabular}




\begin{tabular}{|c|c|c|c|}
\hline Examination & $\begin{array}{l}\text { Low \% of Eligible Stu- } \\
\text { dents }(\mathrm{N}=24)\end{array}$ & $\begin{array}{l}\text { Medium \% of Eligible } \\
\text { Students }(\mathrm{N}=48)\end{array}$ & $\begin{array}{l}\text { High \% of Eligible Stu- } \\
\text { dents }(\mathrm{N}=13)\end{array}$ \\
\hline 2003-2004 Reading, Special Ed. & .245 & .378 & .000 \\
\hline 2003-2004 Reading, Regular Ed. & .624 & .539 & .378 \\
\hline 2003-2004 Math, Special Ed. & .259 & .342 & -.175 \\
\hline 2003-2004 Math, Regular Ed. & .590 & 292 & -.481 \\
\hline 2004-2005 Reading, Special Ed. & .465 & .237 & -.086 \\
\hline 2004-2005 Reading, Regular Ed. & .611 & 467 & .180 \\
\hline 2004-2005 Math, Special Ed. & .561 & .193 & -.115 \\
\hline 2004-2005 Math, Regular Ed. & .580 & .399 & -.102 \\
\hline 2005-2006 Reading, Special Ed. & .374 & -.092 & .166 \\
\hline 2005-2006 Reading, Regular Ed. & .636 & .432 & .068 \\
\hline 2005-2006 Math, Special Ed. & .430 & -.011 & .057 \\
\hline 2005-2006 Math, Regular Ed. & .646 & .457 & .110 \\
\hline 2006-2007 Reading, Special Ed. & .461 & .126 & \\
\hline 2006-2007 Reading, Regular Ed. & .558 & .232 & \\
\hline 2006-2007 Math, Special Ed. & .524 & 279 & \\
\hline 2006-2007 Math, Regular Ed. & .615 & .507 & \\
\hline
\end{tabular}

IJEPL is a joint publication of the Association for Supervision and Curriculum Development, the Faculty of Education at Simon Fraser University, and the College of Education and Human Development at George Mason University. By virtue of their appearance in this open access journal, articles are free to use, with proper attribution, in educational and other non-commercial settings 90 days after initial publication. Copyright for articles published in IJEPL is retained by the authors. More information is available on the IJEPL Web site: http://www.ijepl.org 